\title{
Hybrid Contracts on Sharia Banking: Study on Home Ownership Financing Product by Musharakah Mutanaqishah
}

\author{
Abdul Wahab ${ }^{1 *}$

\begin{abstract}
${ }^{1}$ Sharia Banking Department, Faculty of Islamic Studies, Muhammadiyah Surabaya University, Surabaya, Indonesia *Corresponding author. Email: Wahap1927@gmail.com
\end{abstract}

\begin{abstract}
One form of hybrid contract that is currently widely used by Islamic banking is the Musharakah Mutanaqishah contract; that is, financing products based on the musharakah principle, namely: Shirkah alinan whose portion (hisbah) capital of one of the banks is reduced due to gradual commercial transfers to customers. This research is a qualitative research, with primary and secondary data sources, obtained through observation, interviews, and documentation. With the Huberman and Miles model data analysis method with four steps, namely data collection, data reduction, data display, and data verification. The results showed that the hybrid contract model in the Musharakah mutanaqishah contract on the Muamalat iB KPR product at Bank Muamalat Indonesia Tbk Surabaya Mas Mansur used two separate contracts, the Musharakah and Ijarah contracts. This is in accordance with the provisions of fatwa F DSN-MUI No. 72 year 2008 concerning musharakah mutanaqishah. The application of the musharakah mutanaqishah contract to the KPR Muamalat mortgage products, in terms of harmony and conditions, as well as the use of musharakah and ijarah contracts have also been in line with DSN MUI No. 08/DSN-MUI/IV/200 concerning musharakah and DSN MUI Fatwa Number 09/DSN_MUI/IV/2000 concerning ijarah and also DSN-MUI Fatwa No. 72 of 2008 concerning the Musharakah Mutanaqishah contract.
\end{abstract}

Keywords: hybrid contracts, musharakah mutanaqishah, sharia banking

\section{INTRODUCTION}

\subsection{Background}

The development of the sharia banking industry in Indonesia is so rapid. This industry is able to become the main motor that has contributed to the industrial development of non-bank sharia in the national financial system. The great development of the sharia banking industry can encourage the growth of the sharia insurance industry, the sharia capital market, sharia financing, and sharia mutual funds, and sharia microfinance.

At the end of 2018, Indonesian sharia banking has become the biggest retail Islamic banking in the world which has 23.3 million customers, 3134 bank offices, 1356 sharia services, and 51 thousand employees. In terms of assets, the development of sharia banking and Islamic finance moves quickly, with a very high growth rate of $40-45 \%$ per year. Compared to the growth rate of sharia banking in 92 countries in the world, sharia banking in Indonesia is recorded as the highest growth rate since 2000. Sharia banking assets in Indonesia up to December 2018 have reached IDR 380 trillion [7].

The development of sharia banking must be maintained and improved. One of the efforts to improve the performance of sharia banking is to always deliver product innovations that are relevant to the development of the industrial and business world. Automatic Islamic banking product innovation will also be followed by the contracts that accompany it. One of the sharia bank product innovation models that can be developed is a product model based on hybrid contract (multi contracts).

Hybrid contract is a collection of several material contracts contained in a contract both jointly and reciprocally so that all rights and obligations incurred are seen as a legal consequence of a contract [8]. One form of hybrid contract that is currently widely used by sharia banks is a musharakah mutanaqish contract; that is, financing products based on the musharakah principle, namely: Shirkah al-inan whose portion (hishah) capital of one of the sharik (Sharia Bank/LKS) is reduced due to gradual commercial transfers to customers [9]. There are at least five joint contracts contained in the musharakah mutanaqisah contract, namely: Shirkah, ijarah, wakalah (in leasing management), wa'ad banks to sell in stages, purchases in stages by customers. Musharakah mutanaqishah contracts are usually applied by muamalat banks in product mortgage financing, take over, top up, and credit cards.

\subsection{Research Problems}

a. What is the hybrid contract model in the musharakah mutanaqisah contract on the iB Muamalat mortgage financing product at Bank Muamalat Indonesia Tbk Surabaya Mas Mansur Branch? 
b. How is the application of the musharakah mutanaqisah contract to the iB Muamalat mortgage financing product at Bank Muamalat Indonesia Tbk Surabaya Mas Mansur Branch?

\section{LITERATURE REVIEW}

\subsection{Definition of Hybrid Contract}

According to the fiqh term, the word multi-contract is a translation of the Arabic word al-uqud al-murakkabah which means double contract. Al-'uqud al-murakkabah consists of two words al-'uqud (plural of 'aqd) and almurakkabah. The word 'aqd etymologically means to establish, bind, connect or connect and in Indonesian civil law is defined as an agreement. Whereas in terminology 'aqd means entering into an agreement or bond that results in the emergence of an obligation [6].

Meanwhile, according to al-Imrani, murakkab contract is a set of several material contracts contained by a contract, both jointly and reciprocally, so that all rights and obligations incurred are seen as legal consequences of one contract [8].

\subsection{Various Hybrid Contracts}

Al-'Imrani [8] divides hybrid contacts (multi-faith) into four types, namely: al-'uqudal-mutaqabilah, al-'uqud al mujtami'ah, al-'uqud al-mutanaqidlah wa almutadhadahwa al-mutanafiyah, al- 'uqud al-muktalifah, al'uqud al-mutajanisah. Of the four types, according to him, the first two types, namely al-ququd al-mutaqabilah and alququd al-mujtami'ah, are commonly used hybrid contracts. The following explanation of the five types of hybrid contact:

a. The contract is collected (al-'uqud al-mujtami'ah)

Al- 'uqud al-mujtami'ah is a multi-faith gathered in one contract. Two or more contracts that are compiled into one contract. For example, "I sell this house to you and I rent another house to you for one month for five hundred thousand."

This multi-contract happened because:

1) The gathering of two contracts that have different legal consequences in one contract for two objects at one price.

2) Two different contracts due to the law in one contract for two objects with two prices.

3) Two contracts in one contract which are different in law over an object with one reward, both in the same time or different times.

b. The opposite contract (al-uqud al-mutanaqidhah wa almutadhadahwa al-mutanafiyah).

These three terms, al-mutanaqdhah, al-mutadhadah, almutanafiyah, have in common that all three mean different things. But these three terms have different implications. Mutanaqidhah contains the opposite meaning, as in the example of someone saying something and then saying something else that is contrary to the first. Someone said that something was right, then said something was wrong again. This person's words are called mutanaqidhah, opposites. It is said Mutanaqidhah because between one another do not support each other, but rather break.

c. A different contract (al-uqud al-mukhtalifah).

What is meant by mukhtalifah hybrird contracts is the gathering of two or more contracts that have all the differences in effect between the two contracts or part of it.

Like the difference due to the law in the sale and purchase contract. In a lease agreement there should be a time requirement, whereas in buying and selling vice versa. Another example, the ijarah contract and greetings. In regards, the price of the greeting must be submitted at the time of the contract (fi al-majlis), while in the ijarah, the rental price does not have to be submitted at the time of the contract. The difference between a multi-faith mukhtalifah with a mutanaqidhah, mutantheid, and mutanafiyah lies in the existence of each contract.

d. A similar contract (al-uqud al-mutajanisah).

Al-uqud al-murakkabah al-mutajanisah are contracts that may be collected in one contract, with no influence in law and its legal consequences. This type of multicontract can consist of one type of contract such as a contract of sale and purchase and sale agreement, or several contracts such as sale and purchase and lease. This type of multi-contract can also be formed from two contracts that have the same or different laws.

\subsection{Definition of Musharakah Mutanaqishah}

Musharakah Mutanaqishah is a product derived from the Musharakah contract, which is a form of cooperation between two or more parties. Understanding Musharakah or Syirkah linguistically means al-ikhtilat or merging or mixing. According to the scholars of figh, syirkah in terms of the merging of assets to be used as business capital and the results in the form of profits or losses shared [5].

As for the term definition syirkah is a collaboration between two or more people in a business and the consequences of profits and losses are borne jointly [3]. In other words, it is a legal action between parties who collaborate to run a business based on profit sharing principles according to their agreement.

Related to Mutanaqisah is a word derived from tanaqasayatanaqisu-tanaqisan-mutanaqisun which means to reduce gradually. So that the mention of Musharakah Muatanaqisah is a form of cooperation between two or more parties for ownership of an item or asset. This collaboration will reduce the ownership rights of one party while the other party not. Transfer of ownership through payment mechanisms for other ownership rights. This form of cooperation ended with the transfer of the rights of one party to the other party [4].

As for what is meant by Musharakah Muatanaqisah according to wahbah al zuhaili: Musharakah Muatanaqisah is justified in sharia, because as Ijarah Muntahiyah bi AlTamlik relies on promises from banks to partners (customers) that the Bank will sell to partners its portion of 
ownership in shirkah if partners has paid to the bank the portion price of the bank. During this time, the Musharakah Muatanaqisah was seen as shirkah 'an, because both parties submitted the contribution of ra'sul mall, and the bank delegated to its customers to manage business activities. After completing the shirkah the bank sells all or part of its portion to the partner, provided that the sale agreement is conducted separately which is not related to the shirkah contract" [4].

Meanwhile, according to the National Sharia Council of Majlis Ulama Indonesia, Musharakah Muatanaqisah is a musharakah or syirkah where ownership of assets (goods) or capital of one party (syarik) is reduced due to gradual purchases by other parties [2].

\subsection{The Terms and Conditions of the Musharakah Muatanaqisah Contract}

National Council of Sharia Majlis Ulama Indonesia (DSNMUI), with DSN-MUI fatwa no. 73/DSN-MUI/XI/2008 concerning Muhyarakah Mutanaqisah, in its stipulation it is stated that Musharakah Muatanaqisah follows the provisions contained in the Musharakah contract, namely DSN-MUI fatwa No.08/DSNMUI/IV/2000 concerning musharakah financing, in its fatwa it is mentioned in the pillars of the Musharakah contract, namely DSN-MUI fatwa No.08/DSNMUI/IV/2000 concerning the financing of muhyarakah, in its fatwa it is mentioned that the pillars are in harmony. and Musharakah requirements, which include: [10]

a. A statement of ijab and qabul must be stated by the parties to show their intention in entering into a contract $(\mathrm{akad})$, with due regard to the following matters:

1) Bidding and acceptance must explicitly indicate the purpose of the contract ( $a k a d)$.

2) Acceptance of offers is made at the time of the contract

3) The contract is written down in writing through correspondence or using modern methods of communication.

4) Contracting parties must be competent in law

5) Competent in giving or given power

b. Each partner must provide funds and work, and each partner carries out work as a representative.

c. Each partner has the right to manage musharakah assets in normal business processes.

d. Each partner authorizes the other partners to manage the assets and each of them is deemed authorized to carry out musharakah activities by taking into account the interests of their partners, without committing negligence and deliberate mistakes.

e. A partner is not permitted to withdraw or invest funds in his own interests. Object of contract (capital, work, profit, and loss)

1) Capital

The capital given must be cash, gold, silver, or the same value. Capital consisting of trading assets, such as goods, property, and so on. If the capital is in the form of assets, it must first be valued in cash and agreed by the partners.
The parties may not borrow, lend, donate or gift musharakah capital to other parties, except on the basis of an agreement.

In principle, there are no guarantees in musharakah financing, but to avoid irregularities, Islamic Financial Institutions $(L K S)$ can ask for collateral.

2) Work

The participation of partners in the work is the basis for the implementation of musharakah, but the equality of the work portion is not a requirement. A partner may carry out more work than another, and in this case he/she may demand an additional part of the profit for himself/herself.

Each partner carries out work in musharakah on behalf of the person and representatives of its partners. Each position in the work organization must be explained in the contract.

3) The advantage

a) Profits must be clearly quantified to avoid differences and disputes at the time of profit allocation or termination of musharakah.

b) Each partner's profit must be distributed proportionally on the basis of all profits and no amount is determined in advance for a partner.

c) A partner may propose that if the profit exceeds a certain amount, the excess or percentage is given to him.

d) The profit-sharing system must be clearly stated in the contract.

4) Loss

Losses must be divided among the partners proportionally according to their respective shares in capital.

5) Operational Costs and Disputes

a) Operating costs are charged to joint capital

b) If one party does not fulfil its obligations or if there is a dispute between the parties, then the settlement is carried out through the National Sharia Arbitration Board after an agreement is not reached through deliberation.

6) After completing the sale settlement, all Islamic bank are transferred to other syarik (customers).

a) In special terms the Mushārakah Mutanāqișah Assets can be ijarah to the sharia or other parties.

b) If the Musyarakah asset becomes the object of Ijarah, then syarik (the customer) can rent the asset with the agreed ujrah value.

c) The profit gained from the Ujrah is divided according to the agreed ratio in the contract, while the loss must be based on the proportion of ownership. Profit ratio can follow the change in the proportion of ownership according to the agreement of the sharia.

d) The level of the ownership portion of the Musyarakah syarik asset $(L K S)$ which is reduced due to payment by the syarik (customer) must be clear and agreed upon in the contract.

e) The acquisition cost of Musharakah assets becomes a joint expense while the cost of ownership transfer becomes the buyer's expense. 
09/DSN MUI/IV/2000 about ijarah. Hybrid contract in the musharakah mutanaqishah is allowed provided that it is not made hillah to usury.

Thus, the application of the hybrid contract in the mutanaqishah musharakah contract on the iB Muamalat $K P R$ product is in line with the DSN MUI fatwa. [1]. Concretely, this study illustrates the implementation of hybrid contracts at Bank Muamalat Indonesia Tbk Surabaya Mas Mansur Branch, specifically the application of the musharakah mutanaqis'ah in financing iB Muamalat mortgages for its customers. So, this research is able to make descriptive analysis based on data and facts.

Primary Data Sources were obtained from two sources, namely literature to answer the hybrid contract model, and interviews and observations to answer the application of musharakah mutanaqishah in KPR iB Muamalat products. interviews and observations were made to the Head of Main Branch, Operations Manager, Sharia Supervisory Board, Customer Representative of Bank Muamalat Indonesia Surabaya. While the secondary data source is obtained from documents, literature books that can be accounted for scientifically and there is significance to this research. Documents taken are MMQ financing contracts, SOP, financing rules and so forth.

Inductive data analysis which is carried out through the process of finding and collecting data systematically from the results of interviews, field notes, and documentation. The analytical method used is the interactive method of Huberman and Miles models, namely: data collection, data reduction, data presentation, and data verification.

\section{RESULTS AND DISCUSSION}

\subsection{Hybrid Contract Model in the Musharakah Mutanaqishah Contract}

The Indonesian Ulama Council, through the National Sharia Council, stipulates that the Hybrid contract in the Mushārakah mutanāqișah contract consists of two contracts, namely the syirkah contract and the bai' contract/sale and purchase agreement (which is carried out in parallel) [2]. With the provisions of the syariks in this case Islamic banks and customers:

a. Provide capital and work based on agreement at the time of the contract.

b. Obtain profits based on the agreed ratio at the time of the contract.

c. Bear the loss according to the proportion of capital.

d. In the Mushärakah mutanāqișah covenant, the first party (sharia) is obliged to promise to sell all of its Hishshah gradually and the second party (sharia) must buy it.

e. Buying and selling as referred to in number 3 is carried out according to the agreement.

In the implementation of the Hybrid contract in the mutanaqishah musharaka contract on the Muamalat iB KPR product at Muamalat Indonesia Bank also consists of two main contracts, which are separate namely the Musharakah and Ijarah contracts. This refers to the MUI DSN fatwa number 08/DSN-MUI/IV/200 concerning musharakah. And the MUI DSN fatwa number

\section{B. Application of KPR iB Muamalat Financing with Musharakah Mutanaqishah at Bank Muamalat Indonesia Tbk Mas Mansur Surabaya}

Bank Muamalat Indonesia officially launched the Sharia mortgage loan product $(K P R)$ based on sharia principles since February 2007. At the beginning of the launch of the $K P R$ product, Bank Muamalat Indonesia used the brand name KPRS Baiti Jannati. Since August 2010, Bank Muamalat Indonesia has been striving to improve services to the wider community by increasing the features of its mortgage products by re-launching the brand name that was previously Baiti Jannati, becoming Sharia Housing Financing (PHS), and in 2012 turning into mortgage financing $\mathrm{iB}$ Muamalat until now. $K P R$ iB Muamalat is intended for Individual Indonesian Citizens (WNI) who are at least 21 years old and a maximum of 55 years for employees and 60 years for entrepreneurs and professionals until the due date of the financing period. This financing has several excellent features including.

a. Financing with a term of up to 15 years

b. A minimum down payment of $10 \%$ for houses under type 45 , and $20 \%$ for houses above type 45

c. The existence of a fixed instalment until paid off or a mild instalment opportunity

d. Financing ceiling of up to 25 billion

e. Repayment before maturity there is no penalty.

f. Can be used to finance new and old houses (second), and can take over for financing other types of bank drai

g. High financing value up to $90 \%$ of the home value recognized by the Bank

Customers who want to apply for $K P R$ iB Muamalat financing must meet the requirements specified by Muamalat Bank. Submission requirements are divided into two, namely the requirements for prospective customers and administrative requirements for submission.

After the terms and process of $K P R$ iB Muamalat financing are fulfilled and approved, the next process is the realization of the financing which begins with the signing of the Musharakah Mutanaqisah financing contract, there are two hybrid contracts that must be carried out so that the Mutanaqisah musyarakah contract can proceed. The first contract is a musyarakah agreement between the bank and the customer, to jointly own a house, the second is a lease agreement (Ijarah), in which the customer portion of the rent is directly paid to the bank as the customer's gradual purchase of the portion of bank ownership from the contract object. As stated by Mr. Syaifullah, Branch Head of BMI Mas Mansur:

"There are two contracts in KPR iB Muamalat financing, the first is the musharakah agreement, for joint ownership of the house, the second ijarah contract, where the 
customer portion of the rent rent is directly paid to the bank as a gradual purchase of the customer for the portion of the bank ownership of the contract object"

iB KPR financing agreement from Bank Muamalat Indonesia, the author found that in the implementation of the Mutanaqisah musyarakah contract, it is a combination of two contracts, namely the musyarakah and al-ijarah contracts, and is manifested in two agreements, namely the musyarakah financing contract and the ijarah contract. Furthermore, the bank and each customer contribute capital and risk loading profit and loss in accordance with what was mutually agreed in an agreement. The transfer of use rights over goods or services is done through payment of rental wages, followed by the transfer of ownership of the goods themselves.

Thus, the application of the musharakah mutanaqishah contract on iB Muamalat KPR financing products at Muamalat Indonesia Bank Surabaya Mas Mansur as a mortgage financing contract solution when viewed in terms of harmony and conditions, as well as in terms of using a hybrid contract in $\mathrm{iB} K P R$ products Muamalat based on Musahrakah Mutanaqishah has been in line with the provisions of DSN MUI Number 08/DSN-MUI/IV/200 concerning musharakh. and Fatwa DSN MUI Number 09/DSN_MUI/IV/2000 regarding ijarah.

\section{CONCLUSION}

The hybrid contract model in the mutanaqishah musharakah contract on the Muamalat iB KPR product at Muamalat Indonesia Tbk Bank Surabaya Mas Mansur uses two separate contracts namely Musharakah and Ijarah contracts. This is in accordance with the provisions of fatwa F DSN-MUI No. 1 of 2013 concerning musharakah mutanaqishah.

The application of the musharakah mutanaqisha contract to the KPR Muamalat mortgage products at Bank Muamalat Indonesia Tbk Suarabaya Mas Mansur, in terms of harmony and conditions, as well as the use of musharak and ijarah contracts have also been in line with DSN MUI No.
08/DSN-MUI/IV/200 concerning musharakah. and DSN MUI Fatwa Number 09/DSN_MUI/IV/2000 concerning ijarah.

The Bank also need to increase hybrid contract socialization to Islamic banking stakeholders for market deepening. Musharakah mutanaqishah must be prioritized in its application to financing products, because of its flexibility in anticipating the progress of the business world.

\section{REFERENCES}

[1] Lexy J Moelong, Penelitian Kualitatif (Bandung: Remaja Rosda Karya, 2002)

[2] Fatwa Dewan Syariah Nasional Tentang Musharakah Mutanaqishah (DSN) No.73/DSN/MUI/XI/2008

[3] Abdul Rahman Ghazaly, Gufron Ihsan, Sapiudin Shidiq, Fiqh Muamalah, (Jakarta: Kencana, 2010)

[4] Wahbah Az-Zuhaili, Fiqih Islam Wa Adillatuhu Jilid 5 (Jakarta: Darul Fikir, 2011)

[5] Sayid Syabiq, Fiqh al-Sunnah Vol 3 (Beirut: Dar alFath al-A'lami al-Arabi, 2000)

[6] Luis Malif, Al-Munjid Fil Lunghati wa al-adab wa alUlum (Beirut: Darul Masyruq,1986)

[7] Otoritas Jasa Keuangan, Laporan Perkembangan Keuangan Syariah (Jakarta: OJK Press, 2018)

[8] Abdullah Al-Imrani, al-'Uqud al-Maliyah alMurakkabah (Kairo: Dar al-nadhah, tt)

[9] Fatwa DSN-MUI No 1 Tahun 2013

[10] Fatwa Dewan Syariah Nasional Tentang Musharakah (DSN) No.8/DSN/-MUI/IV/2000 